\title{
Borosilicate glasses with high softening points for glass-ceramic/ copper multilayer substrates
}

\author{
Masahide OKAMOTO, ${ }^{*, \dagger}$ Hirayoshi TANEI, ${ }^{* *}$ Shoichi IWANAGA, ${ }^{*}$ Masato NAKAMURA, ${ }^{*}$ \\ Shosaku ISHIHARA, ${ }^{*}$ Fumikazu TAGAMI ${ }^{* * *}$ and Kazuo SHINOZAKI ${ }^{* * * *}$ \\ *Production Engineering Research Laboratory, Hitachi Ltd., 292, Yoshida-cho, Totsuka-ku, Yokohama 244-0817 \\ ${ }^{* *}$ Industrial Property Cooperation Center, 4-26-5, Koutoubashi, Sumida-ku, Tokyo 130-0022 \\ ${ }^{* * *}$ Hitachi Global Storage Technologies, 1 Kirihara-cho, Fujisawa 252-8588 \\ **** Department of Metallurgy and Ceramics Science, Tokyo Institute of Technology, \\ 2-12-1, Oookayama, Meguro-ku, Tokyo 152-8550
}

\begin{abstract}
We have developed borosilicate glasses with high softening points for glass-ceramic / copper multilayer substrates. The softening points of this glass ranged from $900^{\circ} \mathrm{C}$ to $1000^{\circ} \mathrm{C}$. Glass-ceramics made using this glass barely sintered below $850^{\circ} \mathrm{C}$, but sintered compactly at temperatures just below $1050^{\circ} \mathrm{C}$. Green sheets made using this glass-ceramics could be fired around $850^{\circ} \mathrm{C}$ to remove the binder. Binder removal was caused very fast at this temperature. The glass-ceramics could be co-sintered with copper and had various advantages, such as easy binder removal, a coefficient of thermal expansion approximately equal to that of silicon, a low dielectric constant, sufficient flexural strength, and high water durability. These advantages helped make the manufacturing process of the substrate more productive.
\end{abstract}

(02008 The Ceramic Society of Japan. All rights reserved.

Key-words : Borosilicate glass, Glass-ceramics, Softening point, Copper, Co-fire, Substrate, Binder burn out, Water durability

[Received November 26, 2007; Accepted January 17, 2008]

\section{Introduction}

Since copper has a low resistivity and good electro-migration resistance, it is well-suited to the fabrication of fine conductor lines. Co-sintered with copper, glass-ceramic provides a low coefficient of thermal expansion - approximately equal to that of silicon $\left(3.0 \times 10^{-6} \mathrm{~K}^{-1}\right)$ - a low dielectric constant, and good flexural strength. These characteristics make glass-ceramic/copper multilayer substrates ideal for high-performance computers requiring modules with highly dense conductor wiring. ${ }^{1-9)}$

Glass-ceramics can be made of either crystallized glass without ceramic filler ${ }^{2)-4)}$ or a mixture of glass powders and ceramic powders. ${ }^{5)-9)}$ Since the latter type comes in many varieties, we examined this type of glass-ceramics. First, we investigated commercially available borosilicate glasses, which have a low coefficient of thermal expansion and a low dielectric constant. We were able to find suitable compositions for the mixtures that meet the requirements for the substrate; however two problems arose regarding productivity of the multilayer substrate manufacturing process. One problem was that it took a long time to burn off the organic binder of the green sheet laminates made by using these glasses. The other problem was that boric acid crystallized on the green sheets when the sheets were kept in a highly humid atmosphere. ${ }^{10)}$

The objective of this study is to solve these problems and find a safe and hygienic way of using the water soluble organic binder. We examined the sintering behavior of the various mixtures of glass powders and ceramic fillers and found that the long holding time of heat treatments for binder removal was due to the low softening point of the commercially available borosilicate glass. Additionally, the crystallization of boric acid was due to

Corresponding author: M. Okamoto; E-mail: masahide.okamoto. ex@hitachi.com the poor water durability of borosilicate glass containing a lot of $\mathrm{B}_{2} \mathrm{O}_{3}$. In this paper we describe borosilicate glass with high softening points and high water durability that is well-suited to the efficient fabrication of glass-ceramic/copper substrates.

\section{Experimental procedure}

\subsection{Preparation of samples}

Two commercially available borosilicate glasses are shown in Table 1. In our experiments we mainly used Glass 2; $\mathrm{SiO}_{2}-$ $\mathrm{B}_{2} \mathrm{O}_{3}-\mathrm{K}_{2} \mathrm{O}$ series glass powder. The softening points of this glass is $824^{\circ} \mathrm{C}$. New borosilicate glasses with higher softening points were made by mixing raw materials as $\mathrm{SiO}_{2}, \mathrm{H}_{3} \mathrm{BO}_{3}, \mathrm{Al}_{2} \mathrm{O}_{3}$ and $\mathrm{K}_{2} \mathrm{CO}_{3}$ with a dry ball mill. High grade powders (purity: $99.9 \%$ or higher, Wako Pure Chemical Industries, Ltd., Japan) were used as raw materials for the glass. The procedure for the preparation of the glass powder is as follows. Prescribed amounts of the raw material powders were melted and stirred well in a platinum crucible at $1700-1750^{\circ} \mathrm{C}$. The molten glass was rapidly cooled by being poured from the crucible into water to obtain a glass block. Coarse glass powder, approximately $2 \mathrm{~mm}$ in diameter, was obtained by crushing the glass block in an $\mathrm{Al}_{2} \mathrm{O}_{3}$ mortar. The coarse glass powder was then mechanically ground to obtain powder that would pass through a 100 mesh / inch sieve. Further crushing was achieved by ball milling $0.05 \mathrm{~kg}$ of this powder mixed with ethanol $\left(1 \times 10^{-4} \mathrm{~m}^{3}\right)$ and $\mathrm{Al}_{2} \mathrm{O}_{3}$ balls $(0.4 \mathrm{~kg}$, $10-15$-mm-diameter) in a $4 \times 10^{-4} \mathrm{~m}^{3} \mathrm{Al}_{2} \mathrm{O}_{3}$ pot for $72 \mathrm{~h}$ at 120 $\mathrm{rpm}$. The resulting slurry was dried in air at room temperature to obtain glass powder.

The procedure used for preparation of the green compact is given as follows. Glass powder and ceramic filler powder were mixed with a small amount of $n$-butyl alcohol in an $\mathrm{Al}_{2} \mathrm{O}_{3}$ mortar. The resultant powder was granulated to a -32 mesh powder and uniaxially pressed into a 60 -mm-diameter, 10 -mm-thick disk at 
Table 1. Properties of Commercially Available Borosilicate Glass

\begin{tabular}{lcc}
\hline \multicolumn{1}{c}{ No. } & Glass 1 & Glass 2 \\
\hline Glass type & $\mathrm{SiO}_{2}-\mathrm{B}_{2} \mathrm{O}_{3}-\mathrm{Na}_{2} \mathrm{O}_{\text {glass }}{ }^{* 1}$ & $\mathrm{SiO}_{2}-\mathrm{B}_{2} \mathrm{O}_{3}-\mathrm{K}_{2} \mathrm{O}$ glass $^{* 2}$ \\
\hline Composition & $\mathrm{SiO}_{2}: 83.1 \mathrm{~mol} \%$ & $\mathrm{SiO}_{2}: 81.7 \mathrm{~mol} \%$ \\
& $\mathrm{~B}_{2} \mathrm{O}_{3}: 11.1$ & $\mathrm{~B}_{2} \mathrm{O}_{3}: 17.0$ \\
& $\mathrm{Na}_{2} \mathrm{O}: 3.9$ & $\mathrm{~K}_{2} \mathrm{O}: 1.3$ \\
& $\mathrm{Al}_{2} \mathrm{O}_{3}: 1.8$ & \\
\hline Softening point & $821^{\circ} \mathrm{C}$ & $824^{\circ} \mathrm{C}$ \\
Coefficient of thermal expansion & $3.2 \times 10^{-6} \mathrm{~K}^{-1}$ & $2.3 \times 10^{-6} \mathrm{~K}^{-1}$ \\
Dielectric constant & 4.6 & 4.2 \\
Water durability & good & poor \\
\hline
\end{tabular}

${ }^{* 1}$ ASF1880 (Pyrex glass composition), Asahi Glass Co., Ltd.,

${ }^{* 2}$ GA50, Asahi Glass Co., Ltd.

34.3 $\mathrm{MPa}$ in pressure. No organic binder was added to the green compact during this forming process. The procedure used for preparation of the green sheet is given as follows. A slurry was made by adding a water soluble organic binder (a modified acrylic resin) or an organic solvent soluble organic binder, a dispersing agent, and water or organic solvent to this inorganic powder. An approximately $0.23-\mathrm{mm}$-thick glass-ceramic green sheet was made from the slurry by the doctor-blade method.

\subsection{Measurement}

The green compact was heated at a rate of $100^{\circ} \mathrm{C} \mathrm{h}^{-1}$ to 1000 $1150^{\circ} \mathrm{C}$ in air. A non-contact dilatometer (NC-DM, Rigaku, Japan) was used as the furnace for firing, so that sintering-shrinkage curves could be obtained. The density of the sample after sintering was measured by using the Archimedes method. The softening point of glass was measured by a differential thermal analysis at a heating rate of $3{ }^{\circ} \mathrm{C} \mathrm{min}{ }^{-1}$ in air. The coefficient of thermal expansion was measured by a thermomechanical analyzer (2F-TMA, Rigaku, Japan) at a heating rate of $3^{\circ} \mathrm{C} \min ^{-1}$ $\left(\mathrm{RT}-200^{\circ} \mathrm{C}\right)$ in air. The test pieces for measuring the coefficient of thermal expansion were made by cutting the sample into $3 \times 3 \times 30 \mathrm{~mm}$ sections. The dielectric constant of the sample was calculated by measuring the capacitance of a sintered compact. The sample was cut into $30 \times 30 \times 1 \mathrm{~mm}$ sections and the electrodes $(25 \mathrm{~mm} \Phi)$ were formed by coating $\mathrm{Ag}$ paste (No. 4817, DuPont, USA) on the both sides of the sample, and then dried at $150^{\circ} \mathrm{C}$. A precision LCR meter $(4217 \mathrm{~B}$, Yokogawa Hewlett Packard Co., Japan) was used for measurement of the capacitance. The frequency and signal level of measurement was set to $1 \mathrm{MHz}$ and $1 \mathrm{~V}$, respectively. The dielectric constant; $\varepsilon_{\mathrm{r}}(-)$ of the sample was calculated by substituting the radius of the electrode; $r(\mathrm{~m})$, thickness; $t(\mathrm{~m})$ and capacitance; $\mathrm{C}_{x}(\mathrm{pF})$ of the test piece for the expression (1).

$$
\varepsilon_{\mathrm{r}}=3.6 \times 10^{-2} t \cdot \mathrm{C}_{x} \cdot r^{-2}
$$

The mechanical strength was measured by using the four-point bending test. The width of the lower span was $30 \mathrm{~mm}$ and that of the upper span was $10 \mathrm{~mm}$. The speed of the cross-head was set at $0.5 \mathrm{~mm} \mathrm{m^{-1 }}$. Autograph DSS-5000 (Shimadzu Co., Japan) was used as the text fixture. The size and shape of the test piece for the bending test conformed to the JIS-R-1601 standard. The water durability was measured by putting $1 \mathrm{~g}$ of glass powder and $150 \mathrm{~g}$ of pure water into a $300 \mathrm{ml}$ beaker and covering the beaker with polyethylene film. The beaker was kept at $90^{\circ} \mathrm{C}$ in an oven for $8 \mathrm{~h}$. The water was then centrifuged and filtered.
Boron atoms dissolved in the filtrate were detected by an ICP (Inductively Coupled Plasma) emission spectral analysis. The open porosity of sample was measured by using mercury pressfitting method. The amount of mercury infiltrated to micro pore by pressurizing is that of open pore. A porosimeter (9320 type, Micromeritec Co.) was used for measurement.

\section{Results and discussion}

3.1 Examination of commercially available borosilicate glass

Various ceramic fillers added to the borosilicate glass powders were examined. The suitable mixtures that we found considered of 60-70 vol. \% borosilicate glass, 10-20 vol.\% alumina, and 1030 vol.\% cordierite. Representative properties are shown in Table 2.

The green sheet degradation curves are shown in Fig. 1. The green sheets were made of the mixtures of $65 \mathrm{vol} . \%$ borosilicate glass (Glass 2), 35 vol.\% ceramic filler $\left(\mathrm{Al}_{2} \mathrm{O}_{3}: 15\right.$ vol.\% and cordierite: $20 \mathrm{vol} . \%$ ) and two kinds of organic binders. Green sheet A was used organic solvent soluble organic binder such as thermal depolymerization-type acrylic resin, and green sheet B was used water soluble organic binder such as a modified acrylic resin containing hydrophilic functional groups. In Fig. 1, green sheet $\mathrm{A}$ became lighter at a lower temperature than green sheet $\mathrm{B}$, indicating that for green sheet $\mathrm{B}$, it was difficult to burn off the binder.

The relationship between carbon residue and heat treatment conditions are shown in Fig. 2. The heat treatment was done in an atmosphere of nitrogen and $0.4 \mathrm{~atm} \mathrm{H}_{2} \mathrm{O}$. The green sheet laminates $(50 \times 50 \times 9 \mathrm{~mm})$ were used as samples. In the case of the heat treatment at $750^{\circ} \mathrm{C}$, the green sheet A laminates had less carbon residue than the green sheet $\mathrm{B}$ laminates. A heat treatment holding time of $100 \mathrm{~h}$ was needed at $750^{\circ} \mathrm{C}$ to reduce the

Table 2. Properties of the Glass-ceramic* made using Commercially Available Borosilicate Glass

\begin{tabular}{lc}
\hline Sintering temperature & $950^{\circ} \mathrm{C}$ \\
Coefficient of thermal expansion & $3.0 \times 10^{-6} \mathrm{~K}^{-1}$ \\
Dielectric constant & 4.9 \\
Flexural strength & $230 \mathrm{MPa}$ \\
\hline
\end{tabular}

* 81.7 $\mathrm{SiO}_{2}-17.0 \mathrm{~B}_{2} \mathrm{O}_{3}-1.3 \mathrm{~K}_{2} \mathrm{O}$ glass (mol\%) $\left(\mathrm{D}_{50}: 3.4 \mu \mathrm{m}\right): 65$ vol.\%, $\mathrm{Al}_{2} \mathrm{O}_{3}$ filler $\left(\mathrm{D}_{50}: 2.1 \mu \mathrm{m}\right): 15$ vol. $\%$ and cordierite filler $\left(\mathrm{D}_{50}: 2.1 \mu \mathrm{m}\right)$ : $20 \mathrm{vol} \%$ 


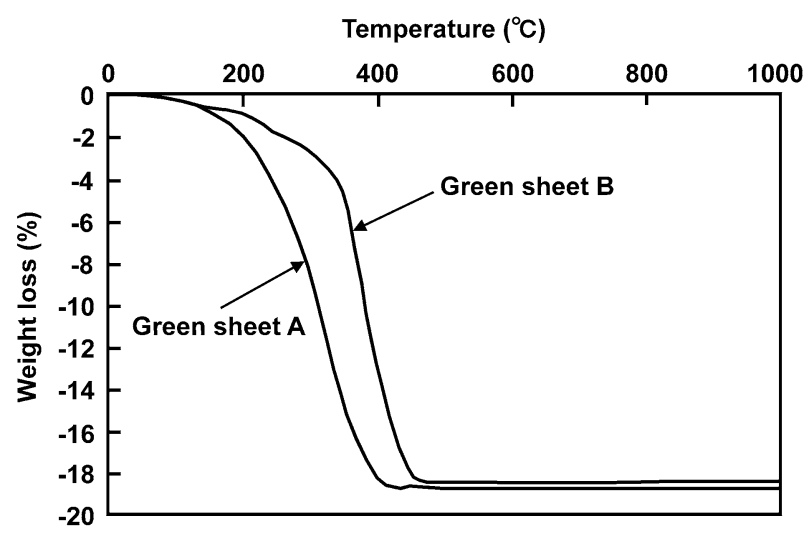

Fig. 1. Glass ceramic* green sheet degradation in nitrogen atmosphere at $100^{\circ} \mathrm{C} \mathrm{h}^{-1}$

* $81.7 \mathrm{SiO}_{2} \cdot 17.0 \mathrm{~B}_{2} \mathrm{O}_{3} \cdot 1.3 \mathrm{~K}_{2} \mathrm{O}$ glass $(\mathrm{mol} \%)\left(\mathrm{D}_{50}: 3.4 \mu \mathrm{m}\right): 65 \mathrm{vol} . \% /$ $\mathrm{Al}_{2} \mathrm{O}_{3}\left(\mathrm{D}_{50}: 2.1 \mu \mathrm{m}\right): 15$ vol.\%/cordierite $\left(\mathrm{D}_{50}: 2.1 \mu \mathrm{m}\right): 20$ vol.\% Green sheet A: organic solvent soluble organic binder (thermal depolymerization-type acrylic resin)

Green sheet B: water soluble organic binder (a modified acrylic resin containing hydrophilic functional groups)

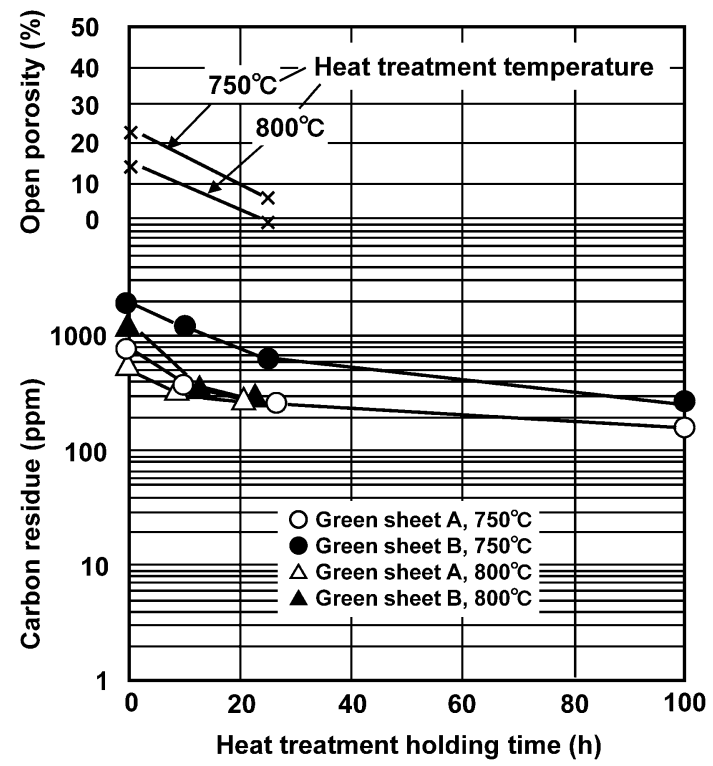

Fig. 2. Carbon residue and open porosity after heat treatment of glassceramic* green sheet laminates in $\mathrm{N}_{2}+0.4 \mathrm{~atm} \mathrm{H}_{2} \mathrm{O}$.

* 81.7 $\mathrm{SiO}_{2} \cdot 17.0 \mathrm{~B}_{2} \mathrm{O}_{3} \cdot 1.3 \mathrm{~K}_{2} \mathrm{O}$ glass (mol\%) $\left(\mathrm{D}_{50}: 3.4 \mu \mathrm{m}\right): 65 \mathrm{vol} . \% /$ $\mathrm{Al}_{2} \mathrm{O}_{3}\left(\mathrm{D}_{50}: 2.1 \mu \mathrm{m}\right): 15$ vol.\%/cordierite ( $\left.\mathrm{D}_{50}: 2.1 \mu \mathrm{m}\right): 20$ vol. $\%$

Green sheet A: organic solvent soluble organic binder (thermal depolymerization-type acrylic resin)

Green sheet B: water soluble organic binder (a modified acrylic resin containing hydrophilic functional groups)

carbon residue to less than the target of $200 \mathrm{ppm}$. However, a heat treatment held for $24 \mathrm{~h}$ at $800^{\circ} \mathrm{C}$ resulted in almost the same amounts of carbon residue for both green sheet laminates, suggesting that the water soluble binder could be burned off as efficiently as the organic solvent soluble binder if the heat treatment was done at $800^{\circ} \mathrm{C}$ or higher. In this case, however, the open porosity of the glass-ceramic was nearly $0 \%$, so binder removal did not proceed any more.

The relationship between carbon residue and heat treatment conditions of the alumina green sheet laminates made by using

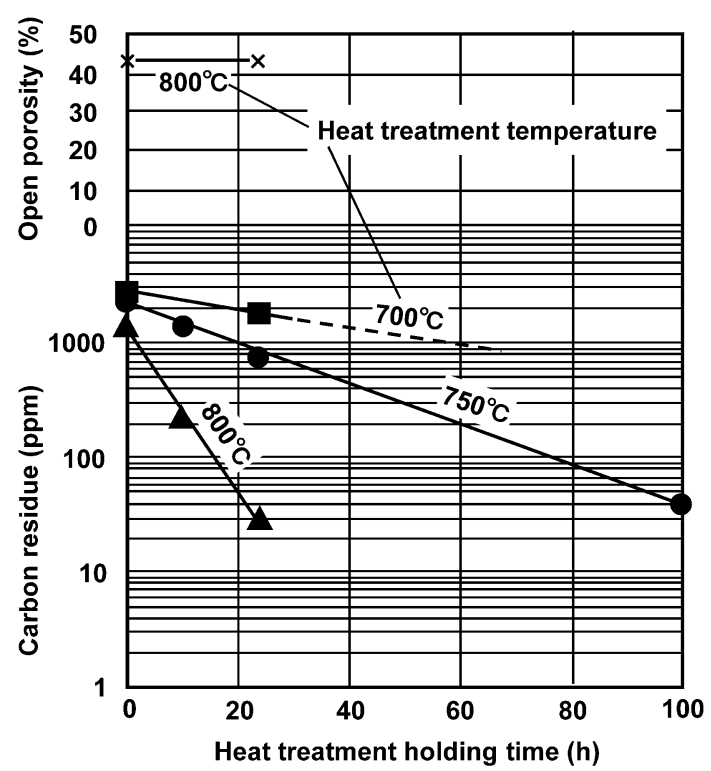

Fig. 3. Carbon residue and open porosity after heat treatment of alumina green sheet* laminates in $\mathrm{N}_{2}+0.4$ atm $\mathrm{H}_{2} \mathrm{O}$.

* Water soluble organic binder (a modified acrylic resin containing hydrophilic functional groups)

water soluble binder are shown in Fig. 3. As the heat treatment holding time was increased, the amount of carbon residue decreased. Since the alumina did not sinter below $1000^{\circ} \mathrm{C}$, the open porosity of the alumina green sheet laminates was kept at about $43 \%$ for heat treatments up to $800^{\circ} \mathrm{C}$. The rate of decreasing carbon residue was especially high at $800^{\circ} \mathrm{C}$, because the following reaction between carbon and water gas causes the carbon dioxide at $800^{\circ} \mathrm{C}$ or higher.

$$
\mathrm{C}+2 \mathrm{H}_{2} \mathrm{O} \rightarrow \mathrm{CO}_{2}+2 \mathrm{H}_{2}
$$

The rate constant of reaction (a) $k$ is shown by equation (b).

$$
k=A \exp (-E / R T)
$$

In equation (b), $A$ is frequency factor, $E$ is activation energy of reaction (a), $R$ is gas constant and $T$ is absolute temperature. When the logarithm of both sides of expression (b) is taken, Eq. (b) is converted to Eq. (c).

$$
\ln k=\ln A-E / R T
$$

The reaction rate constant; $\mathrm{k}$ of carbon removal reaction (a) at $750^{\circ} \mathrm{C}$ and $800^{\circ} \mathrm{C}$ for $0-10 \mathrm{~h}$ is calculated $70 \mathrm{ppm} / \mathrm{h}$ and $89 \mathrm{ppm} /$ h, respectively from Fig. 3 . When these values are substituted for the expression (c), and $\mathrm{A}$ and $\mathrm{E}$ are obtained to $1.19 \times 10^{4} \mathrm{ppm} /$ $\mathrm{h}$ and $43.7 \mathrm{~kJ} / \mathrm{mol}$, respectively.

In the case of the glass-ceramic made by using commercially available borosilicate glass, the heat treatment for binder removal had to be done below $800^{\circ} \mathrm{C}$, because it sinters compactly around $800^{\circ} \mathrm{C}$. This was the reason for the inefficient binder removal.

We thought that binder removal would be more efficient at $800^{\circ} \mathrm{C}$ or higher. A glass-ceramics that barely sinters below $800^{\circ} \mathrm{C}$ but sinters compactly at temperatures just below $1050^{\circ} \mathrm{C}$ was needed. The temperature of $1050^{\circ} \mathrm{C}$ is slightly lower than the melting point of copper $\left(1083^{\circ} \mathrm{C}\right)$. As the content of ceramic filler in the glass-ceramic was increased, the glass-ceramic sintered less and less around $800^{\circ} \mathrm{C}$. However it did not sinter compactly at temperatures just below $1050^{\circ} \mathrm{C}$. Consequently, we concluded it was necessary to develop a borosilicate glass with a 


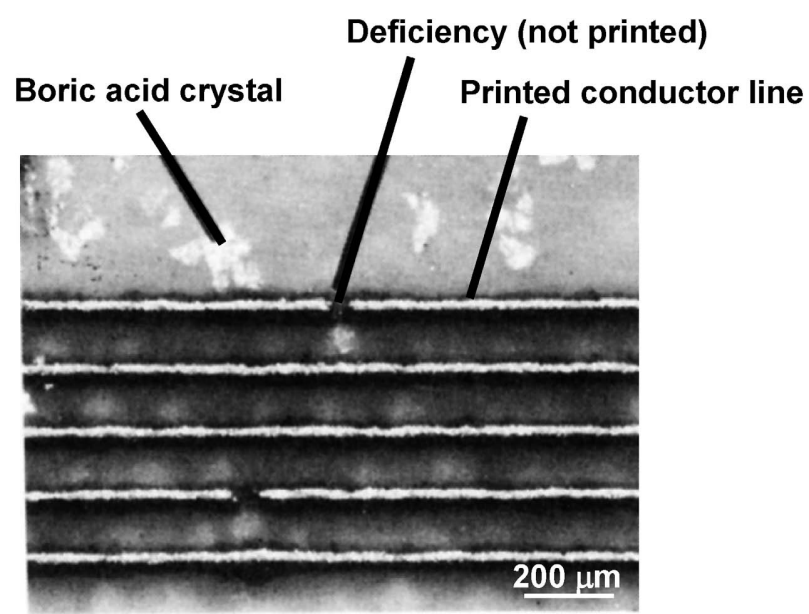

Fig. 4. An example of deficiency in $\mathrm{Cu}$ conductor printing line due to crystallized boric acid on glass ceramic green sheet.

high softening point.

We found an additional problem that boric acid crystallized on the green sheet made by using the $\mathrm{SiO}_{2}-\mathrm{B}_{2} \mathrm{O}_{3}-\mathrm{K}_{2} \mathrm{O}$ glass in a highly humid atmosphere. ${ }^{10)}$ This was because the water durability of the glass was so poor that the glass component $\mathrm{B}_{2} \mathrm{O}_{3}$ dissolved in the water. The crystallized boric acid caused a deficiency in $\mathrm{Cu}$ conductor printing line as shown in Fig. 4. Cu paste is not printed on the part where boric acid crystallized.

\subsection{Examination of borosilicate glass with a high soft- ening point}

To solve the problems described above, we tried to develop a borosilicate glass that contained more $\mathrm{SiO}_{2}$ and less $\mathrm{B}_{2} \mathrm{O}_{3}$ than commercially available borosilicate glass. We made many borosilicate glasses, and examined two with softening points of about $900^{\circ} \mathrm{C}$ and about $1000^{\circ} \mathrm{C}$ i.e. $\mathrm{G} 900$ and $\mathrm{G} 1000$. The compositions of these glasses are $\mathrm{SiO}_{2}: 87.4, \mathrm{~B}_{2} \mathrm{O}_{3}: 8.1, \mathrm{Al}_{2} \mathrm{O}_{3}: 1.8, \mathrm{~K}_{2} \mathrm{O}$ : $2.7 \mathrm{~mol} \%$ and $\mathrm{SiO}_{2}: 90.9, \mathrm{~B}_{2} \mathrm{O}_{3}: 8.4, \mathrm{~K}_{2} \mathrm{O}: 0.7 \mathrm{~mol} \%$, respectively. The sintering shrinkage curves of the green sheet laminates made by using these glasses and the glass-ceramics are shown in Fig. 5, along with those of commercially available borosilicate glass. The curves of relative density were converted from dilatometric curves. The shift to higher temperatures due to the higher softening points can be observed.

The sintering shrinkage curves suggested the best heat treatment temperature. The temperature for binder removal seemed to be related to the temperature at which the green sheet laminate sintered to about $65 \%$ in relative density. We chose $65 \%$ as a relative density at which binder removal occurred enough. Moreover, the temperature for densification of the green sheet laminate seemed to be related to the temperature at which the green sheet laminate sintered to about $95 \%$ in relative density. These temperatures are shown in Fig. 6. The optimum temperature for binder removal was over $800^{\circ} \mathrm{C}$, and the optimum temperature for densification must be below $1050^{\circ} \mathrm{C}$. The mixture of the borosilicate glass with a softening point of $900^{\circ} \mathrm{C}$ and $0-35$ vol.\% ceramic filler, as well as the mixture of the borosilicate glass with a softening point of $1000^{\circ} \mathrm{C}$ and $0-23$ vol. $\%$ ceramic filler, satisfied the above conditions, Ceramic filler contents mainly affected the flexural strength of the glass-ceramics. Suitable content ranged from 20 to 35 vol. $\%$.

The $\mathrm{B}_{2} \mathrm{O}_{3}$ dissolution from the $\mathrm{SiO}_{2}-\mathrm{B}_{2} \mathrm{O}_{3}-\mathrm{K}_{2} \mathrm{O}$ glass powder into hot water is shown in Fig. 7. The amount of $\mathrm{B}_{2} \mathrm{O}_{3}$ dissolution

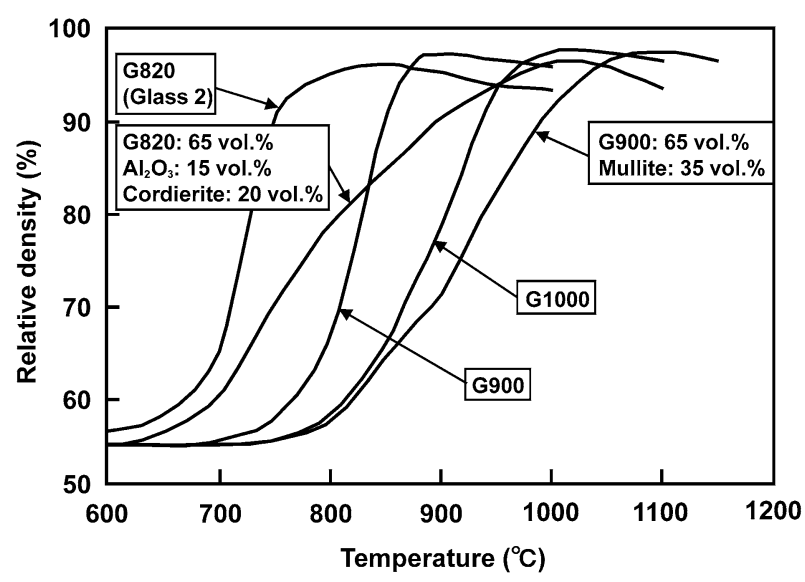

Fig. 5. Dilatometric curves of binder-free green compact for borosilicate glasses and composites of borosilicate glass/ceramic filler in air at $100^{\circ} \mathrm{C} \mathrm{h}^{-1}$.

G900: the glass with softening point $900^{\circ} \mathrm{C}$

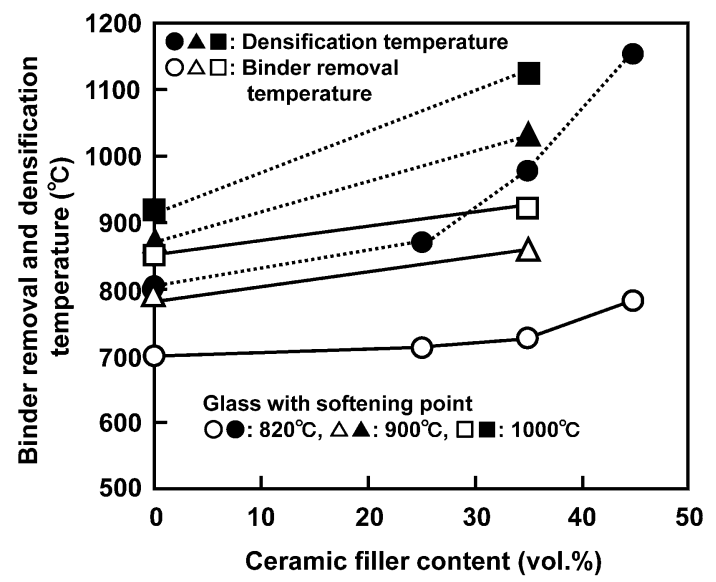

Fig. 6. Binder removal and densification temperatures of borosilicate glass/ceramic filler composites in $\mathrm{N}_{2}+0.4 \mathrm{~atm} \mathrm{H}_{2} \mathrm{O}$.

Binder removal temperature: the temperature at which relative density of glass ceramics reach $65 \%$

Densification temperature: the temperature at which relative density of glass ceramics reach $95 \%$

Ceramic filler: mullite $\left(\mathrm{D}_{50}: 2.1 \mu \mathrm{m}\right)$

Binder: water soluble organic binder (a modified acrylic resin containing hydrophilic functional groups)

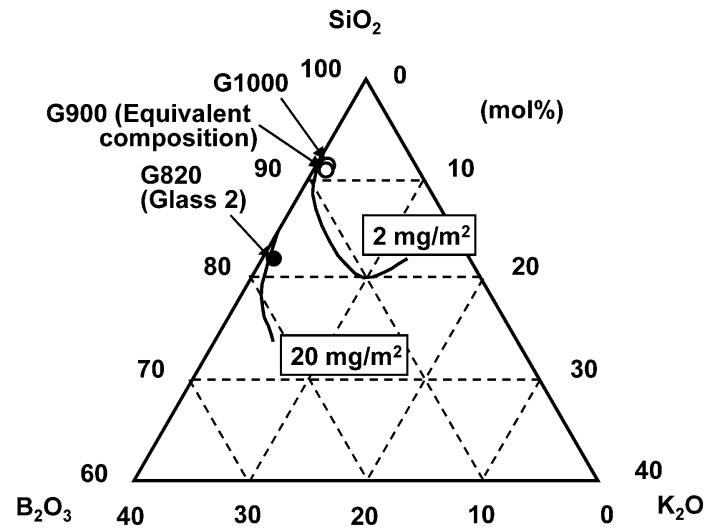

Fig. 7. Equivalent $\mathrm{B}_{2} \mathrm{O}_{3}$ dissolution curves of the $\mathrm{SiO}_{2}-\mathrm{B}_{2} \mathrm{O}_{3}-\mathrm{K}_{2} \mathrm{O}$ glass powder. 
Table 3. Properties of the Glass-Ceramic ${ }^{*}$ Made using the New Borosilicate Glass

\begin{tabular}{lc}
\hline Sintering temperature & $1000^{\circ} \mathrm{C}$ \\
Coefficient of thermal expansion & $3.1 \times 10^{-6} \mathrm{~K}^{-1}$ \\
Dielectric constant & 5.3 \\
Flexural strength & $220 \mathrm{MPa}$ \\
Boric acid crystallization & None \\
Temperature for binder removal & $\geq 850^{\circ} \mathrm{C}$ \\
Holding time for binder removal & about $10 \mathrm{~h}$ \\
\hline
\end{tabular}

* 87.4 $\mathrm{SiO}_{2} \cdot 8.1 \mathrm{~B}_{2} \mathrm{O}_{3} \cdot 1.8 \mathrm{Al}_{2} \mathrm{O}_{3} \cdot 2.7 \mathrm{~K}_{2} \mathrm{O}$ glass $(\mathrm{mol} \%)\left(\mathrm{D}_{50}: 3.9 \mu \mathrm{m}\right): 70$ vol.\%, mullite filler ( $\left.\mathrm{D}_{50}: 2.1 \mu \mathrm{m}\right): 30 \mathrm{vol} . \%$

Binder: water soluble organic binder (a modified acrylic resin containing hydrophilic functional groups)

was derived from the amount of B dissolution from the surface area of glass powder. The amount of B dissolution from glass powder was measured by ICP emission spectral analysis. The surface area ratio of glass powder was measured by BET surface area ratio measurement devices. The $\mathrm{B}_{2} \mathrm{O}_{3}$ dissolution of commercially available $\mathrm{SiO}_{2}-\mathrm{B}_{2} \mathrm{O}_{3}-\mathrm{K}_{2} \mathrm{O}$ glass (G820 (Glass 2)) was $20 \mathrm{mg} / \mathrm{m}^{2}$. The borosilicate glass whose $\mathrm{B}_{2} \mathrm{O}_{3}$ dissolution was 2 $\mathrm{mg} / \mathrm{m}^{2}$ or less did not crystallize boric acid on the green sheet in the highly humid atmosphere. The equivalent $\mathrm{B}_{2} \mathrm{O}_{3}$ dissolution curves showed that as the $\mathrm{B}_{2} \mathrm{O}_{3}$ contents were decreased, the amounts of $\mathrm{B}_{2} \mathrm{O}_{3}$ dissolution decreased. When the $\mathrm{K}_{2} \mathrm{O}$ content was almost the same as the $\mathrm{B}_{2} \mathrm{O}_{3}$ content, the amounts of $\mathrm{B}_{2} \mathrm{O}_{3}$ dissolution became low. Considering the borosilicate glass structure, in the case of a $\mathrm{B}$ atom coordinated with three oxygen atoms, $\mathrm{B}_{2} \mathrm{O}_{3}$ dissolves more easily than in the case of a $\mathrm{B}$ atom coordinated with four oxygen atoms. ${ }^{11), 12)}$ The addition of $\mathrm{K}_{2} \mathrm{O}$ caused the decrease in the $\mathrm{B}_{2} \mathrm{O}_{3}$ dissolution rate, which can be attributed to the increase of a $\mathrm{B}$ atom coordinated with four oxygen atoms. ${ }^{11), 12)}$

The new glass (G900) we developed had both high softening point and high water durability. Glass-ceramics (G900: 70 vol.\%, mullite filler: 30 vol.\%) made by using this new glass had various advantages, as shown in Table 3. In particular, the heat treatment holding time for binder removal of the new glasses was decreased to about one-tenth of that of commercially available glasses.

\section{Conclusion}

1) The softening point of the glass consist of $\mathrm{SiO}_{2}: 87.4$, $\mathrm{B}_{2} \mathrm{O}_{3}: 8.1, \mathrm{Al}_{2} \mathrm{O}_{3}: 1.8, \mathrm{~K}_{2} \mathrm{O}: 2.7 \mathrm{~mol} \%$ (G900) and the glass consist of $\mathrm{SiO}_{2}$ : $90.9, \mathrm{~B}_{2} \mathrm{O}_{3}: 8.4, \mathrm{~K}_{2} \mathrm{O}: 0.7 \mathrm{~mol} \%(\mathrm{G} 1000)$ is $900^{\circ} \mathrm{C}$ and $1000^{\circ} \mathrm{C}$, respectively.

2) The composite of G900 and 0-35 vol.\% ceramic filler and the composite of G1000 and 0-23 vol.\% ceramic filler have $65 \%$ or less in relative density at $800^{\circ} \mathrm{C}$ and $95 \%$ or more at $1050^{\circ} \mathrm{C}$.

3) $\mathrm{B}_{2} \mathrm{O}_{3}$ dissolution of $\mathrm{G} 900$ and $\mathrm{G} 1000$ were $2 \mathrm{mg} / \mathrm{m}^{2}$ or less and boric acid did not crystallize on the green sheet consist of which glass and ceramic filler in the highly humid atmosphere.

4) The composite containing $70 \mathrm{vol} \% \mathrm{G} 900$ and 30 vol. $\%$ mullite filler has the following properties: a) sintering temperature of $1000^{\circ} \mathrm{C}$; b) coefficient of thermal expansion $\left(\mathrm{RT}-200^{\circ} \mathrm{C}\right)$ of $3.1 \times 10^{-6} \mathrm{~K}^{-1}$; c) relative dielectric constant of 5.3 at $1 \mathrm{MHz}$; d) flexural strength of $220 \mathrm{MPa}$.

\section{References}

1) R. R. Tummala, J. Am. Ceram. Soc., 74[5], 895-908 (1991).

2) A. H. Kumar, S. Knickerbocker and R. R. Tummala, Proceedings of $42^{\text {nd }}$ Electronic Components \& Technology Conference, 678-681 (1992).

3) R. N. Master, L. W. Herron and R. R. Tummala, IEEE Trans. On Comp., Hybrid \& Manuf. Tech., 14[4], 780-783 (1991).

4) S. H. Kinckerbocker, A. H. Kumar and L. W. Herron, Am Ceram Soc Bull, 72[1], 90-95 (1993).

5) K. Niwa, N. Kamehara, K. Yokouchi and Y. Imanaka, Advanced Ceramic Materials, 2, No. 4, October, 832-835 (1987).

6) K. Niwa, N. Kamehara, H. Yokoyama, K. Yokouchi and Y. Imanaka, Advanced in Ceramics, 19, 41-47 (1987).

7) K. Niwa, Y. Imanaka, N. Kamehara and S. Aoki, Advances in Ceramics, 26, 323-337 (1989).

8) N. Kamehara, Y. Imanaka and K. Niwa, Denshi Tokyo, 26, 143-148 (1987).

9) Y. Shimada, K. Utsumi, M. Suzuki and H. Takamizawa, Electron Compon Conf, 33, 314-319 (1983).

10) J. H. Jean, Jpn. J. Appl. Phys., 35, L429-L431 (1996).

11) P. B. Adams and D. D. Evans, Mater. Sci. Res., 12, 525-537 (1978).

12) B. C. Bunker, D. R. Tallant and T. J. Headley et al., Phys. and Chem. of Glasses, 29[3], 106-120 (1988). 